\title{
A rich ichnofossil assemblage from the Frasnian (Upper Devonian) deposits at Andoma Hill, Onega Lake, Russia
}

\author{
RADEK MIKULÁŠ, SANDIJS MEŠKSIS, ALEXANDER IVANOV, ERVINNS LUKŠEVIČS, IVARS ZUPIŅŠ \& \\ ĢIRTS STINKULIS
}

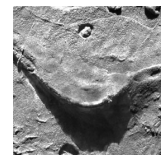

\begin{abstract}
Trace fossils and ichnofabrics were recognized in the Middle to Upper Devonian deposits of the East European Platform at the Onega Lake (NW Russia), developed as the Old Red Sandstone facies. The studied sequence is aged from the upper Givetian to the Middle Frasnian. The most diverse ichnoassemblage was ascertained in the earliest Frasnian (lower to middle part of the Andoma Formation), comprising the ichnogenera ?Arenituba, Cochlichnus, Cruziana, Diplocraterion, Lockeia, Palaeophycus, Planolites, Rusophycus, Skolithos, Teichichnus, and Undichna. Combination of ichnologic and sedimentary data points to the assumption that these deposits probably originated in wave- and tide-influenced environments, possibly in a brackish-water estuary. Towards the middle Frasnian, Skolithos-like trace fossil dominate; the ichnoassemblage can be attributed to the tidally influenced channels and bars. - Key words: ichnology, East European Platform, Main Devonian field, Old Red Sandstone facies.
\end{abstract}

MiKULÁŠ, R., MEŠĶIS, S., IVANOV, A., LUKŠEVIČs, E., ZuPIN̦Š, I. \& STINKULIS, Ģ. 2013. A rich ichnofossil assemblage from the Frasnian (Upper Devonian) deposits at Andoma Hill, Onega Lake, Russia. Bulletin of Geosciences 88(2), 389-400 (3 figures, 1 table). Czech Geological Survey, Prague. ISSN 1214-1119. Manuscript received April 6, 2012; accepted in revised form December 5, 2012; published online February 4, 2013; issued June 7, 2013.

Radek Mikulášs, Institute of Geology, Academy of Sciences of the Czech Republic, Rozvojová 269, 16502 Praha 6, Czech Republic; mikulas@gli.cas.cz•Sandijs Mešksis, Ervīns Lukševičs \& Girts Stinkulis, Department of Geology, University of Latvia, Rainis Boulevard 19, Riga LV-1586, Latvia • Alexander Ivanov, Department of Palaeontology, St. Petersburg University, 16 Liniya 29, 199178 St. Petersburg, Russia •Ivars Zupiņš, Natural History Museum of Latvia, K. Barona Street 4, Riga LV-1010, Latvia

Ichnofossils have been recognized as a peculiar entity in the fossil record (Nathorst 1881), as a useful tool for recognition of certain parameters of the environment (e.g., Seilacher 1953, 1967a; Buatois et al. 1998) and, in terms of intensity of bioturbation, as an integral part of description of sedimentary rocks (Reineck 1963, Droser \& Bottjer 1986). In certain facies, also paleobiological significance (e.g., evidence of occurrence of certain organisms and/or life strategies) is crucial.

The usefulness of trace fossils as indicators of sedimentary environments (see Knaust \& Bromley 2012 for modern overview) was proved also for the Old Red Sandstone facies, which originated chiefly during the Middle and Late Devonian in Laurussia supercontinent. Therefore, it is represented also in the East European Platform, representing its easternmost part (e.g., Friend et al. 2000). Other occurrences are in Spitzbergen, Greenland, Norway, Great Britain, USA and Canada, being represented mostly by terrigenous siliciclastic deposits of late- to post-orogenic foreland and intramontane molasse basins, with occasional marine influence (e.g., Friend et al. 2000).
The Old Red Sandstone facies played an important role in the history of ichnology: its occurrence and favourable exposures in the Great Britain made it attractive in the beginning of modern geology (and ichnology as its part). Therefore, also trace fossils were mentioned during this period (Smith 1909). Old Red Sandstone showed a potential for providing data on very early colonization of land (e.g., Morrissey \& Braddy 2004). Numerous palaeobiologically focused ichnological studies of the facies were accomplished (e.g., Carroll \& Trewin 1995); ichnologic data were also used for reconstruction of sedimentary environments within the Old Red Sandstone facies (e.g., Blomeier et al. 2003).

Ichnofossils from the Middle-Upper Devonian deposits of the East European platform, including those of the Old Red Sandstone facies, have not been studied in detail. The only relevant minor papers on the topic are those by Hecker (1930), Ivanov (2005), Mikuláš \& Dronov (2006), despite the rather long history of palaeontological research conducted in this territory. The above-quotated papers deal mostly with the Givetian-Frasnian combined clastic-carbonate deposits of 
the north-western Russia, and even less data is known from the siliciclastic sequences of the same age; only Engalichev (2003) presented a brief report.

The Andoma Hill locality is a well known site of vertebrate, invertebrate, plant and trace fossils, which is located in the north-eastern proximity of the Main Devonian field of the East European Craton and is characterized by the Old Red Sandstone facies. The site is located at the south-eastern bank of the Onega Lake, in Vytegra district of the Vologda Government, Russia, where various siliciclastic rocks form high cliffs along the lake shore. These deposits are locally strongly influenced by Quaternary glacial deformations. As the object of geological importance, the Andoma Hill has attracted the attention of geologists for several centuries: the samples of fossils have been collected since the beginning of the $19^{\text {th }}$ century, and the Devonian vertebrates from the Andoma Hill were for the first time mentioned by Erofeev (1846) and Pander (1857) and later were reported by various authors (Petrov 1956; vertebrates identified by D. Obruchev, see Obruchev \& Mark-Kurik 1965, Ivanov 1990). Yet scientific research in ichnology begins only with the description of trace fossils by Engalichev (2003).

Extensive material of fossil vertebrates was collected at the Andoma Hill by members of joint expeditions of St.-Petersburg University, University of Latvia, the Natural History Museum of Latvia, and Institute of Geology, Komi Research Centre (Syktyvkar) during several field seasons from 2002 to 2007. The comprehensive sampling provided remarkable fossil material including trace fossils, and some preliminary results of the detailed sedimentological and palaeontological studies were recently reported (Ivanov et al. 2006). Geological section of the Devonian deposits cropping out at the Andoma Hill was lithologically subdivided into three formations, and preliminary data on the vertebrate assemblages characterising the sequence were published. Besides vertebrate remains, many of trace fossils have been discovered and collected, which allows a significant supplement to the previously described ichnoassemblage (Engalichev 2003). The aim of this study is to specify the sedimentary environment of the Devonian deposits cropping out at Andoma Hill based on the results of ichnofossil studies, and to give a general characterization of the Andoma locality within the Old Red Sandstone facies.

\section{Geological settings}

The Andoma Hill is situated on the $2 \mathrm{~km}$ long and about $1 \mathrm{~km}$ wide peninsula at the south-eastern coast of the Onega Lake, in a distance of $c a 500 \mathrm{~km}$ to the east from St.-Petersburg, about $40 \mathrm{~km}$ to north from the town of Vytegra, Vologda Region of Russia. The Andoma Hill is composed of most probably glaciotectonically dislocated Middle-Upper Devonian deposits, overlain by a thin Quater- nary cover, cropping out about $2 \mathrm{~km}$ south from the mouth of the Andoma River. The highest point of the Andoma Hill lies close to Gnevashevskaya village at $83.8 \mathrm{~m}$ a.s.l. In some places, these deposits form up to $55 \mathrm{~m}$ high cliffs along the coast of the lake. The Devonian deposits crop along the shore of the Onega Lake in the northern and south-western parts of the peninsula in a distance of about $3.5 \mathrm{~km}$, as well as along some ravines with steep slopes. The north-western margin of the peninsula is covered by a dense spruce forest growing on the Devonian clay underlying the thin layer of soil; hence no outcrops are developed here.

Localities along the northern and south-western margins of the Andoma Hill are stratigraphically well documented. Based upon the detailed stratigraphic studies along the northern margin, three formations of siliciclastic deposits have been recently established (Ivanov et al. 2006). Some details of the sequence were described also in several previous works (Barkhatova 1941, Petrov 1956, Snigirevskaya \& Snigirevsky 2001, Engalichev 2003). The three lithostratigraphical units, from the oldest to youngest, are as follows.

1. The Pavlikovskaya Formation consists of fine and very fine-grained weakly cemented quartzose sandstone, which is typically brown or dark red, alternating with moderately thin $(0.2-0.4 \mathrm{~m})$ beds of clayey siltstone. A significant portion of the sequence consists of poorly sorted siliciclastic rocks with abundant mica. Obscure sedimentary structures do not allow defining precisely the origin of the deposits, but planar bedding, weakly defined cross-stratification, erosional surfaces and channels present in some places suggest that deposits accumulated in fluvial settings (Tovmasyan \& Stinkulis 2008). Rare disarticulated placoderm, sarcopterygian and psammosteid remains were found only in the uppermost part of the sequence (Ivanov et al. 2006), but no ichnofossils have been reported from this formation. The age determination is based on the vertebrate assemblage, and the Pavlikovskaya Formation was dated as the Upper Givetian.

2. The Andoma Formation unconformably overlies the Pavlikovskaya Formation. It consists of the alternation of highly variegated deposits: fine- and very fine-grained sandstone and sand (dominating), clay and silty clay, siltstone (Fig. 2). Medium- and coarse-grained sandstone, intraformational conglomerate with clay rolls and fish bones are also present in the Andoma Formation. The quartzose sandstones are more abundant at the base, and sandstone alternation with siltstones and clay occurs towards the top. In places, frequent alternation of thin $(3-5 \mathrm{~cm})$ layers of siltstone and fine-grained sandstone occurs. Sandy deposits show various sedimentary structures such as a well-defined trough cross-stratification characteristic for the subaqueous dunes, and abundant, up to $1 \mathrm{~m}$ thick beds with ripple lamination. Planar bedding characterises the clay and siltstone deposits. Colour of deposits varies to a high degree. Composition and various sedimentary structures of the Andoma Formation, such as wave ripple 
Figure 1. Sketch maps showing a geographical position of the Andoma Hill and extent of the fossil sites along the coast of the Onega Lake.

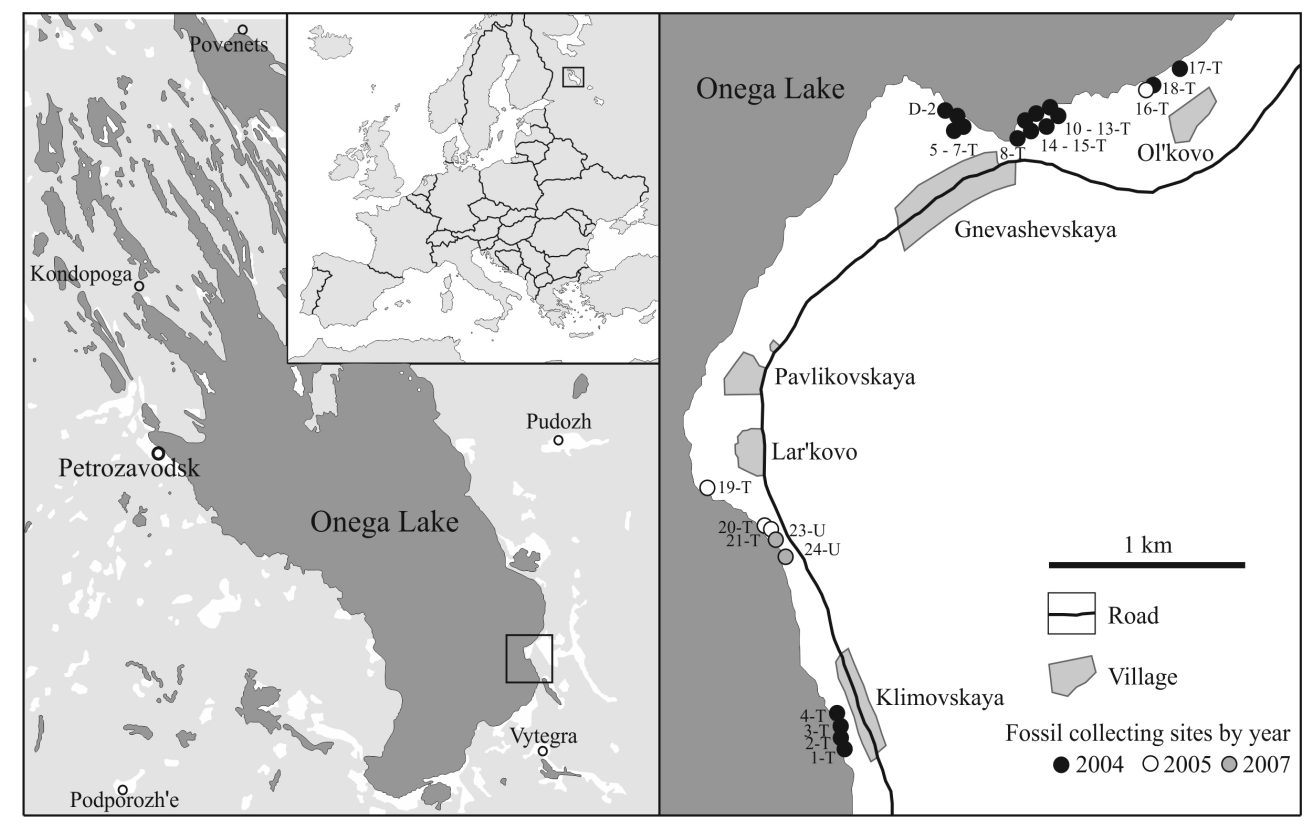

Klimovskaya Formation. Nevertheless, this part of the sequence contains the most abundant assemblage of vertebrate remains ever been found in Andoma Hill. Besides, large portions of archaeopterid plant stems (Snigirevskaya \& Snigirevsky 2001) and rare moulds of bivalves and gastropods were reported from this part of the section.

Spring and neap tide cycles in several cross-beds, sand bars and signatures of subaqueous dunes support the interpretation that the sandstones of the Klimovskaya Formation accumulated mainly in migration of dunes by traction currents (Tovmasyan \& Stinkulis 2008). Fossils provide an evidence of the longevity of formation of these sands, probably, during early and middle part of the Frasnian, judging from the findings of Psammosteus falcatus Obruchev in the uppermost part of the section. Psammosteus falcatus in the Baltic succession is distributed in the Snezha-Pamušis interval, tentatively correlated with the rhenana conodont zone (Esin et al. 2000).

\section{Localities investigated}

More than 20 fossil sites were exploited during the research (Fig. 1), but the ichnofossils (apart of indeterminable ichnofabric) have been found only in several localities. Nomenclature of localities for the northern margin of the Andoma Hill follows that proposed by Ivanov et al. (2006, fig. 2), while nomenclature of localities along the southwestern margin of the Andoma Hill is proposed here. Most specimens are kept at the Natural History Museum of Latvia (NHML, Riga), collection No. LDM Pl 14, and at The Saint Petersburg University, collection No. 65.

Locality N3. - The locality is situated at the northern edge of 
the Andoma Hill, in a distance of several tens to hundreds of metres north from the Gnevashevskaya village. Deposits of the almost complete Andoma Formation and the lower and middle part of the Klimovskaya Formation crop out here in a high cliff. Beds of the Andoma Formation are heavily glaciotectonically disturbed with the dip angle reaching $85^{\circ}$, whereas sandstones of the Klimovskaya Formation are less disturbed. The lowermost portion of the Andoma Formation section (interval 2.3-2.5 m above the lower boundary) consists of brownish violet clayey siltstones with abundant $S k o$ lithos isp., 3 to $16 \mathrm{~mm}$ in diameter. Overlying brownish, very fine sandstone contains less frequent Skolithos-like trace fossils, which reach about $6 \mathrm{~mm}$ in diameter.

The next interval with well visible bioturbational structures $(4.4-5.1 \mathrm{~m})$ corresponds to three beds of silty clay and siltstone with burrows, which superficially resemble those from the interval $2.3-2.5 \mathrm{~m}$. The lower about $30 \mathrm{~cm}$ thick bed of rock of brownish violet tint yields rare, long burrows, which are about $2 \mathrm{~cm}$ in diameter. The middle bed, about $40 \mathrm{~cm}$ thick layer of the maroon coloured siltstone contains rather abundant, densely spaced burrows usually with the diameter about $1 \mathrm{~cm}$. Overlying bed of the maroon siltstone (about $30 \mathrm{~cm}$ thick) demonstrate many shallow and wide burrows, which may reach $2.5 \mathrm{~cm}$ in diameter and do not exceed $5 \mathrm{~cm}$ in depth.

Some horizontal burrows appear on the lower surface of the light fine-grained sandstone overlying the layer of brown siltstone at interval $18.75 \mathrm{~m}$ above the lower boundary of the formation. These burrows have been found in association with the small remains of vertebrates including denticles of Psammosteus, and small fragments of plants.

Locality S4. - Exposure of glaciotectonically heavily disturbed deposits of the Andoma Formation stretches along the south-western margin of the Andoma Hill in a distance of about $250 \mathrm{~m}$ from the southern end of Lar'kovo village. Here, in the upper part of the Andoma Formation just some tens of centimetres below its upper boundary, the trace fossil Phycodes (?) was observed (2004), together with vertebrate remains within the fish-bearing bed No. 20-T. Small Skolithos-type shafts reaching only $2-3 \mathrm{~cm}$ in depth and several $\mathrm{mm}$ in diameter were noticed in the bed of siltstone, $70 \mathrm{~cm}$ below the bed 20-T. During the next years, the exposure changed dramatically due to erosion and retreat of the coastal line, therefore a different situation was found during the field season of 2007. An intercalation of the $2-3 \mathrm{~cm}$ thick bands of grey sandstone, typically with flaser or lenticular lamination, with the $0.5 \mathrm{~cm}$ thin laminae of brownish silty clay approximately $50 \mathrm{~cm}$ below the upper boundary of the Andoma Formation was discovered. Skolithos-like shafts reaching only $2-3 \mathrm{~mm}$ in diameter and $1.5-2 \mathrm{~cm}$ in depth are moderately spaced within the sandy beds, with the upper part partly embedded in the overlying clay. Vertical burrows are frequent, situated at the distance of 1.2-2 cm of each other. In places, the upper surface of clayey deposits bears horizontal trace fossils of the Planolites type, filled with sandy material, which are $2-3 \mathrm{~mm}$ in diameter; they do not form a network.

Locality S5. - The site is located at the south-western margin of the Andoma Hill in approximately equal distance from Lar'kovo and Klimovskaya villages. The largest part of the Andoma Formation and the lower portion of the Klimovskaya Formation form the high cliff here. Several beds of the "fish-breccias" have been collected here (23-U, 24-U, 25-U) in the middle part of the Andoma Formation. An intercalation of sandy and clayey material above the fish-bearing layer 23-U contains a relatively diverse assemblage of ichnofossils including Cochlichnus, Cruziana, Monomorphichnus, Palaeophycus, and Planolites (samples 25-U), and it shows desiccation cracks accompanied by Planolites.

Locality S8. - The locality is situated in the southern neighbourhood of the outcrops at the south-western margin of the Andoma Hill, approximately opposite of the southern end of Klimovskaya village. Many trace fossil samples have been collected from the scree and on the beach of the lake (specimens No LDM Pl 14/50-14/60). These fossils most probably derived from the middle part of the Andoma Formation (corresponding to the 23-U "fish-breccia" from locality S5) and they correspond to the richest assemblage of ichnofossils containing such ichnogenera as Cochlichnus, Cruziana, Diplocraterion, Glockerichnus, Lockeia, Palaeophycus, Planolites, Rusophycus, Skolithos, Teichichnus, and Undichna. These trace fossils are preserved as epi- and hyporeliefs in the very fine-grained sandstone beds. In the same locality, but in the upper part of the section of Andoma Formation about $17 \mathrm{~m}$ below the boundary with the overlying Klimovskaya Formation, a sandstone bed with abundant Diplocraterion and less frequent Skolithos has been found in situ.

\section{Intensity of bioturbation}

The ichnofabric index (ii, Droser \& Bottjer 1986) was estimated for some layers, and measured for some samples from the locality S8, in a scree, collecting site 2-T. The results are summarized in Table 1.

Table 1. Ichnofabric index of selected samples from the S8 locality.

\begin{tabular}{llcc}
\hline No. & Specimen No. & Bioturbated fabric (\%) Ichnofabric index \\
\hline 1 & P1 14/50 upper surface & 20.6 & 3 \\
2 & P1 14/50 lower surface & 35.6 & 3 \\
3 & P1 14/51 & 2.5 & 2 \\
4 & P1 14/52 & 27.0 & 3 \\
5 & P1 14/56 & 28.6 & 3 \\
6 & P1 14/57 & 15.8 & 3 \\
\hline
\end{tabular}




\section{Systematic ichnology}

Ichnogenus Arenituba Chamberlain, 1971

\section{?Arenituba isp.}

Figure 3C

Material. - A sole find from the Cruziana Bed (between 14-T and 15-T).

Description. - Straight or very slightly curved tunnels on the upper surface of a sandstone slab; these are partly preserved as oblique cross-sections of full relief, partly as concave epireliefs, radiating from an oval bulge that probably represents a cast of a vertical shaft. The central bulge, not sharply bordered, is about $4 \mathrm{~mm}$ in diameter. Width of the radial rays is $3-4 \mathrm{~mm}$. These are not distributed evenly around the bulge. On one side (i.e., left side on a photograph), a "gap" of $130^{\circ}$ without a preserved ray exists. Total number of well-defined rays is seven. Their length is also variable but obviously influenced by a selective preservation. The largest preserved ray is $26 \mathrm{~mm}$ long.

Remarks. - A typical fodinichnion or agrichnion is probably concerned, but the exact determination according to a sole specimen is difficult. The grooves may represent individual surficial or subsurface feeding probes. The presented ichnotaxonomical distinguishing follows the paper of Stanley \& Pickerill (1995). For further discussion, also the ichnogenus Skolichnus (Uchman, 2010) can be considered.

\section{Ichnogenus Cruziana d'Orbigny, 1842}

\section{Cruziana isp.}

Figure 3A

Material. - At least three specimens from the so-called "Cruziana bed", i.e. between the beds 14-T and 15-T; few additional poorly preserved specimens.

Description. - Small, short, straight to very moderately curved horizontal bilobate burrows (convex hyporeliefs), 1-1.5 mm wide, bearing poorly- to well-visible oblique striae.

Figure 2. Geological section of the Andoma and Klimovskaya formations cropping along the coast of Onega Lake at Andoma Hill (simplified after Ivanov et al. 2006). Grain size: c - clay, s - silt, vfs - very fine-grained sand, fs - fine-grained sand, ms - medium-grained sand, cs - coarse-grained sand, g - gravel, $\mathrm{p}$ - pebbles.
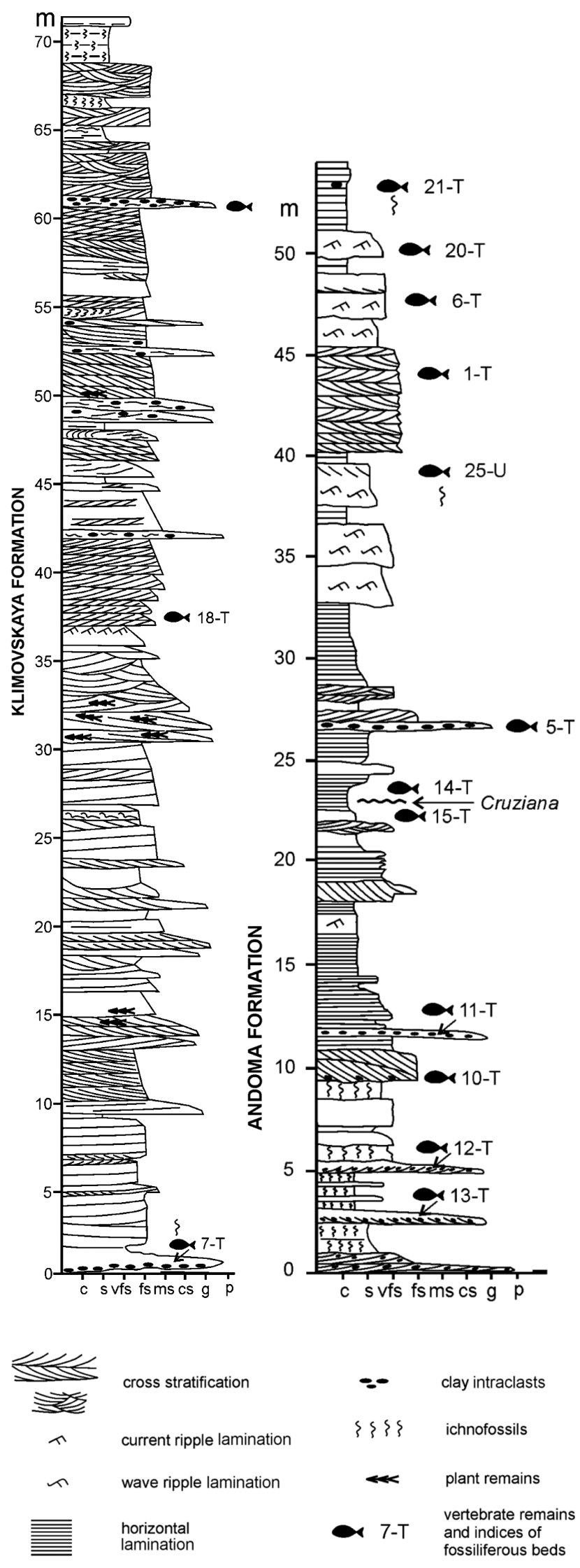
Remarks. - Cruziana represents mostly repichnia of trilobites (e.g., Fillion \& Pickerill 1990) or other benthic arthropods (e.g., Bromley 1996).

\section{Ichnogenus Diplocraterion Torell, 1870}

\section{Diplocraterion paralellum Torell, 1870 Figure 3B}

Material. - Dozens observations in situ on the S8 locality, several collected samples (e.g., LDM P1 14/61-14/63).

Description. - Cross-sections of vertical structures, showing a pair of circular "scars" interconnected by a straight thinner lamina of a reworked material. The whole 3-D structure represents most probably vertical U-shaped tubes showing a spreiten-structure between the U limbs. The "scars" are approximately $1.0 \mathrm{~mm}$ in diameter, unlined. Distance of the openings is in average $6 \mathrm{~mm}$.

Remarks. - In the upper part of the Andoma Formation (S8 site), approx. $17 \mathrm{~m}$ below the contact with the Klimovskaya Formation, a layer with Diplocraterion (samples LDM Pl 14/61-14/63) was found. Engalichev (2003) determined this trace fossil as Corophioides ( $c f$. Baldwin 1977) but its morphologic features fit better to Diplocraterion. For description, relations and figures of the ichnogenus and particular ichnospecies see e.g. Fürsich (1974), Häntzschel (1975), Crimes et al. (1977), Bjerstedt (1988), Bjerstedt \& Ericksson (1989), Fillion \& Pickerill (1990). According to these authors, Diplocraterion is a dwelling burrow of suspension feeders, characteristic of settings with stronger wave and current energy.

\section{Ichnogenus Lockeia James, 1879}

\section{Lockeia silliquaria James, 1879}

\section{Figure 3D}

\section{Material. -(LDM Pl 16/40 Lockeia and Palaeophycus).}

Description. - Smooth, almond-shaped bulges preserved as low convex hyporeliefs. Dimensions of the bulges range from $4 \times 1 \mathrm{~mm}$ to $10 \times 2.5 \mathrm{~mm}$.

Remarks. - The morphologically simple trace is considered to be a cubichnion of bivalves. For the description of the ichnogenus, its origin and representatives see, e.g., Maples \& Suttner (1990), Schlirf et al. (2001).

\section{Ichnogenus Palaeophycus Hall, 1847}

Palaeophycus tubularis Hall, 1847

Figure 3D

Material. - Two specimens (full reliefs) preserved in the Cruziana Bed, i.e. between 14-T and 15-T.

Description. - Straight, smooth tunnels (full reliefs). These are damaged/compacted in a typical way: relief of the margins is higher than the central part. This approved the assumption that the tunnels had strongly lined walls. Diameter of both specimens ranges from 5 to $6 \mathrm{~mm}$; length of preserved parts is 65 or $80 \mathrm{~mm}$, respectively.

Remarks. - Systematic determination of the finds follows the work of Pemberton \& Frey (1982). These traces are considered to be domichnia.

\section{Ichnogenus Phycodes Richter, 1850}

\section{?Phycodes isp.}

Figure $3 \mathrm{~F}$

Material. - A sole find (convex hyporelief showing casts of cross-sectioned tunnels) from the bed below 25-U.

Description. - Set of six systematically arranged "scars" that resulted from a partial passive filling of an open burrow (tunnel) system. The orientation of these "scars" shows that the tunnels were branched, probably in a fanlike way. The fragmentary casts of individual tunnels are ca $5 \mathrm{~mm}$ in diameter; they intersect the bedding plane in acute angles $10-20^{\circ}$. Size of the whole structure is approx. $2 \times 4 \mathrm{~cm}$.

Remarks. - Phycodes is one of the most common feeding traces in the Palaeozoic. For a description of the ichnogenus and ichnospecies and their relations see, e.g., Fillion \& Pickerill (1990), and Han \& Pickerill (1994).

\section{Ichnogenus Planolites Nicholson, 1873}

\section{Planolites beverleyensis (Billings, 1862)}

Figure 3E

Material. - Dozens of collected specimens and few hundreds specimens observed in situ.

Description. - Straight, moderately to conspicuously curved, smooth, exceptionally branching tunnels of circular outline, parallel to oblique to the bedding, preserved as 

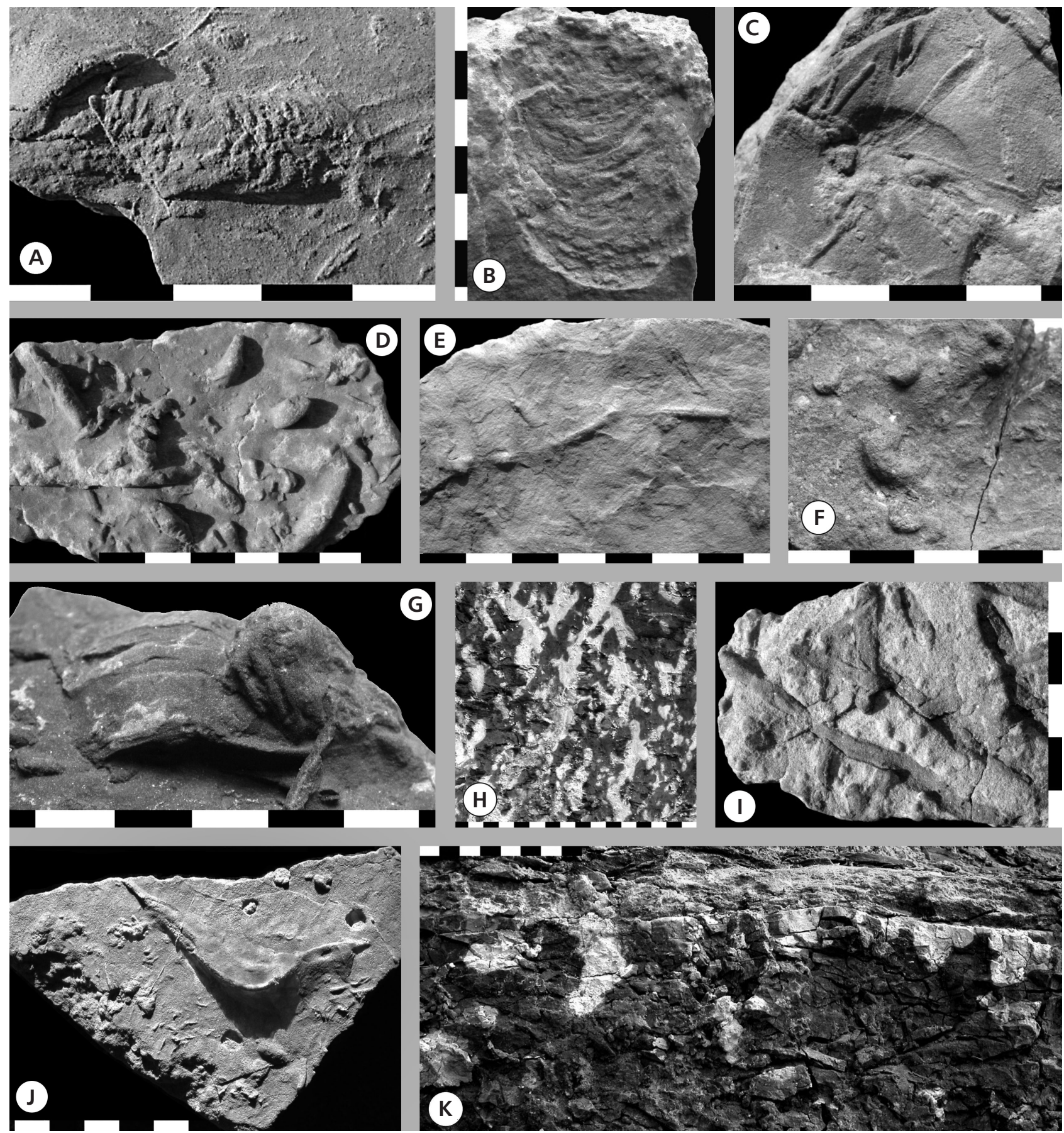

Figure 3. Ichnofossils from Andoma Hill, Onega Lake, Russia; all specimens from the Upper Devonian Andoma Formation. Scale in centimetres. -A - Cruziana isp., convex hyporelief, LDM Pl 14/53. • B - Diplocraterion paralellum, full relief - vertical aspect, LDM Pl 14/61. $\bullet$ C - ?Arenituba isp., convex hyporelief, LDM Pl 14/50. D - Lockeia silliquaria (right and bottom) and Palaeophycus tubularis (left), LDM Pl 14/60. $\bullet$ E - Planolites beverleyensis, convex hyporelief and full relief, LDM Pl 14/54. • F - ?Phycodes isp., convex hyporelief, LDM Pl 14/64. $\mathrm{G}-$ ?Rusophycus isp., convex hyporelief, LDM Pl $14 / 58$. $\bullet \mathrm{H}$ - Skolithos isp. in the clayey deposits with digenetic precipitates; vertical section, field photograph. • I - Teichichnus rectus, full relief, LDM Pl 14/55. - J - Undichna isp., LDM Pl 14/50. • K - Skolithos isp. in the clayey deposits with digenetic precipitates; vertical section, field photograph.

full reliefs or convex hyporeliefs. Diameter of tunnels ranges usually from 2 to $6 \mathrm{~mm}$; length of preserved sections may reach few decimetres. Tunnels present on one bed or bedding plane show usually a constant diameter.
In the Andoma Hill, Planolites was found in $25-\mathrm{U}$ bed, i.e. in the upper part of the Andoma Formation (locality S5). Specimens from this bed are only $20 \mathrm{~mm}$ in diameter and can be several tens of $\mathrm{cm}$ long, forming simple curved 
burrows oriented horizontal or oblique to bedding. Specimen LMD Pl 14/60 (Fig. 3E) of Planolites is wider (more than $5 \mathrm{~mm}$ ), not strongly curved. At S4 locality, horizontal burrows of Planolites are filled by sandy material. The diameter of the horizontal burrows is $2-3 \mathrm{~mm}$. All the finds of Planolites from Andoma occur 4 to $10 \mathrm{~cm}$ below lower bedding planes of sandstones, i.e., in the underlying shales.

Remarks. - Planolites is interpreted as a feeding burrow made by a worm-like animal. Planolites typically belongs to entirely of shallow-tier traces, in some cases with discernible Planolites-associated ichnofabrics that include the Thalassinoides and Chondrites ichnofabrics, which may even be interbedded within the same channel-fill succession. The diversity and size of the burrows varies with the amount of oxygen in deposits; maximum burrow diameter is under lowered oxygen condition ( $c f$. Savrda \& Bottjer 1986, 1987).

Assignment of these traces to P. beverleyensis follows the paper by Pemberton \& Frey (1982).

\section{Ichnogenus Rusophycus Hall, 1852}

\section{?Rusophycus isp.}

Figure 3G

Material. - Two specimens on a sole rock slab, LDM Pl $14 / 58$.

Description. - Coffee-bean shaped bilobate pits dissected longitudinally by ridges. In one case, the ridge is wellvisible; in the second case it is indistinct. Maximum width of the specimens is 11 , or $12 \mathrm{~mm}$, respectively. Estimated length of both the specimens is $20 \mathrm{~mm}$. Surface of the lobes of one specimen is smooth but it is slightly weathered. The second specimen shows irregular, isolated casts of scratches on certain portion of the surface. Depth of the pit is 3-4 mm.

Remarks. - Overall morphology of the trace corresponds to Rusophycus; this ichnogenus is typically preserved as a convex hyporelief, showing striae made by individual tracemaker's limbs during the burrowing. Rusophycus is very often found in the Early Palaeozoic Cruziana ichnofacies. Undoubtedly the cubichnia of trilobites (less frequent other arthropods) are concerned. Individual ichnospecies are described in details, e.g., by Osgood (1970), Seilacher (1970), Crimes (1975), Crimes \& Marcos (1976), Baldwin (1977), Crimes et al. (1977). In the case of the Andoma traces, a common tracemaker with the traces described as Cruziana isp. is likely, due to the spatial relationships and similarities in size and morphology.

\section{Ichnogenus Skolithos Haldeman, 1840}

\section{Skolithos isp.}

Figure $3 \mathrm{H}, \mathrm{K}$

Material. - Several finds from the lowermost part of the Andoma section (between 10-T and 12-T layers); LDM sample Pl 14/50 (between 14-T and 15-T) bearing incompletely preserved ?Skolithos isp. (eight distinctive circular "scars").

Description. - In the interval between 10-T and 12-T layers, shafts up to $10 \mathrm{~cm}$ (exceptionally more) deep and $0.7-1.5 \mathrm{~cm}$ in diameter occur in several layers. These are unlined, vertical, and more or less straight. On the sample Pl 14/50 (bearing also Undichna isp.), rounded knobs or pits, $0.5-0.7 \mathrm{~cm}$ in diameter, appear in two small clusters.

Remarks. - Skolithos is the ichnofossil giving the name to the Skolithos ichnofacies (e.g., Seilacher 1967b, Frey \& Pemberton 1984), which characterizes shifting substrates under a high level of water waving and currents. For systematic ichnology of Skolithos and its ichnospecies see, e.g., Osgood (1970), Alpert (1974, 1975), Fillion \& Pickerill (1990), Schlirf \& Uchman (2005). Skolithos is typically a dwelling burrow. The material on the sample Pl 14/50 can be attributed to Skolithos with certain probability only: the possibility that the circular cross-sections belong to other, more complex ichnotaxon comprising vertical shafts (e.g., Thalassinoides) exists.

\section{Ichnogenus Undichna Anderson, 1976}

\section{Undichna isp.}

Figure 3J

Material. - A sole specimen LDM Pl 14/50.

Description. - Generally sinusoid, somewhat asymmetrical, deep and large ridge (convex hyporelief), basically $\mathrm{V}$-shaped in cross-section. Estimated wavelength of the sinusoid is $10 \mathrm{~cm}$ but only $7 \mathrm{~cm}$ of the ridge is preserved. Estimated amplitude is $20 \mathrm{~mm}$.

Remarks. - Modern revision of Undichna was done by Trewin (2000) and Minter \& Braddy (2006). Recently, Fillmore et al. (2011) contributed by further comments. Our understanding to the trace follows these papers. 


\section{Ichnogenus Teichichnus Seilacher, 1955}

\section{Teichichnus rectus Seilacher, 1955}

Figure 3I

Material. - 7 specimens on a sole sample collected in the Cruziana Bed (between 14-T and 15-T).

Description. - Irregularly arranged, densely crowded, mutually cross-cutting spreiten-structures resembling troughs filled up in a vertical plane. These are preserved in full reliefs, partly weathered-out, on an upper bedding plane of the sandstone slab. The troughs are straight; preserved parts are 1-7 $\mathrm{cm}$ long and $\mathrm{ca} 4 \mathrm{~mm}$ wide. The trace is composed usually of a small number (2-4) of troughs. In vertical plane, all traces probably show a shape of a very broad "U" letter.

Remarks. - Teichichnus is a very frequent infaunal feeding trace known from the Late Proterozoic up to Cenozoic. Description, figures and discussions are, e.g., in the papers of Seilacher (1955), Baldwin (1977), Crimes et al. (1977), Frey \& Howard (1982), Frey \& Bromley (1985), Crimes (1987), Bjerstedt \& Ericksson (1989).

\section{Discussion}

The richest assemblage of the trace fossils is observed in the middle part of the Andoma Formation. On the surfaces of very fine-grained sandstone, the following ichnogenera have been discovered as epi- and hyporeliefs: ?Arenituba, Cochlichnus, Cruziana, Diplocraterion, Lockeia, Palaeophycus, Planolites, Rusophycus, Skolithos, Teichichnus, and Undichna. In the upper part of the Andoma Formation, in fine- to medium-grained sandstones, a different assemblage of trace fossils is observed. It is much less diverse and contains only Diplocraterion and Skolithos. This assemblage possibly indicates the presence of the Skolithos ichnofacies typical of the shallow water environment. The Skolithos-like trace fossils are rather widely distributed in the section and are usually associated with layers of silty and clayey deposits; such distribution shows that various tracemakers inhabited the sea floor almost permanently except several barren beds. Yet the intensity of bioturbation indicates that the colonization intervals were usually short, presumably due to the rapid sedimentation.

The Andoma Formation comprises two distinct ichnofacies: the Skolithos ichnofacies in the lower and upper part and the Cruziana ichnofacies in the middle part. The Skolithos tracemakers are usually interpreted as organisms living in shifting substrates, and the Skolithos ichnofacies is indicative of high energy, intertidal to near-shore marine environments. The Skolithos tracemakers are considered to be suspension-feeders that could include marine polychaetes, sipunculan and phoronid worms, or even possibly fish and sea-anenomes (Bromley 1996). Cruziana represents mostly repichnia of trilobites (e.g., Fillion \& Pickerill 1990) or other benthic arthropods (e.g., Bromley 1996). The Cruziana ichnofacies represents a diverse behavioral spectrum, including dwelling, resting, crawling, feeding and escape responses. This ethologic diversity characterizes the ichnofacies and reflects low- to medium-energy conditions with occasional fluctuations of high-energy settings (storm beds) and high concentrations of both suspended and detrital food. The Cruziana ichnofacies, besides open seas below the fair-weather wave base, represents shallow marine or epeiric sea settings, such as estuaries, bays and lagoons (e.g., Frey \& Pemberton 1984). Composition and various sedimentary structures of the Andoma Formation allow supposing that these deposits probably originated in wave- and tide-influenced environment. Absence of storm-induced structures suggests deposition in shallow water, above the wave base (Tovmasyan \& Stinkulis 2008). These sedimentological data coincides with ichnofacies interpretation.

Trace fossils in the Klimovskaya Formation are much rarer than in the Andoma Formation. In the upper part of the Klimovskaya Formation, bioturbational structures with Skolithos were found in two siltstone beds. Spring and neap tide cycles in several cross-beds, sand bars and signatures of subaqueous dunes support the interpretation that the sandstone sequence of the Klimovskaya Formation accumulated most possibly in tidally-influenced channels and bars (Tovmasyan \& Stinkulis 2008). Transportation of large amount of sand indicates proximity to the continent, and it is known that Skolithos can be formed not only in the wave zone with high energy but also in deltaic marine environments (Bromley 1996) or even in dune environments (Gregory et al. 2006).

Salinity is a critical factor for nearly all types of benthic life. Only the euryhaline organisms from brackish and hypersaline environments are able to adjust to different osmotic pressures. Most marine and freshwater organisms are stenohaline, i.e., they can tolerate only minor or none deviations of salinity.

In the palaeoenvironmental reconstructions, mixture of traces characteristic of both the Skolithos and Cruziana ichnofacies sometimes has been interpreted as brackish water fauna (Pemberton \& Wightman 1992). Brackish water fauna can be considered an impoverished marine assemblage, with endobenthic forms more abundant than the epibenthic ones. However, based on insufficient evidence of brackish conditions, the Cruziana ichnofacies typical of the Andoma Formation probably originated in lower shoreface to the nearshore shelf ebb tidal deltas and byhead deltas; interpretation of sedimentary environment as lagoonal (Engalychev \& Nikitin 2001) is inacceptable because of domination of clastic sediments.

The Cruziana and Skolithos ichnofacies are typically recorded in estuarine systems (Ranger \& Pemberton 
1992, Pemberton et al. 1992, MacEachern \& Pemberton 1994, Gingras et al. 2012). Estuarine valleys are typically incised during a sea-level fall. They may begin to fill during a lowstand, but sediments accumulate during the subsequent sea-level rise (Zaitlin et al. 1994). In lowstand, coarse-grained sediments are deposited and preserved; they are replaced vertically by finer-grained facies of the transgressive system tract. During a lowstand, the valley acts as a by-pass zone, or lowstand deposits are eroded and reworked during the subsequent transgression and transgressive deposits directly overlie the sequence boundary. As transgression proceeds, brackish-water conditions reach the upper estuary channels and the mixed ichnofacies migrates landward. Normal salinity waters in the estuary may progressively allow the establishment of the more marine Cruziana ichnofacies (MacEachern \& Pemberton 1994).

The present hypothesis, based on previously published sedimentologic data and the new ichnologic evidence, is that the mixed Cruziana-Skolithos ichnofacies in the middle part of the Andoma Formation may characterize conditions of a brackish-water estuary.

Detailed account of criteria for distinguishing estuaries in the geologic record using trace fossils has recently been accomplished by Gingras et al. (2012). The criteria comprise (1) the presence of brackish water in estuaries and the biologic/ichnologic response of the lowered salinity, and (2) the ichnologic response of marine transgressions traceable in fills of incised valleys. Concerning the second criterion, the geologic profile in Andoma does not provide evidence of transgressive surfaces that are usually demarcated by a suite of firmground trace fossils.

The criteria for lowered salinity are manifold and they include the identification of ethological generalist behaviour, diminution of tracemakers/trace fossils, lowered diversity, high population density, preference of infaunal habits compared to epifaunal behaviour, and longitudinal trends of landward freshening of depositional waters. Moreover, Gingras et al. (2012) suggested a list of "marine" trace fossils; their occurrence diminishes the probability of lowered salinity. These are Nereites, Zoophycos, Spirophyton, Chondrites, Rhizocorallium, Asterosoma, Phoebichnus, robust Rosselia and large-diameter Ophiomorpha.

The assemblage of trace fossils described in this paper, i.e. ?Arenituba, Cochlichnus, Cruziana, Diplocraterion, Lockeia, Palaeophycus, Planolites, Rusophycus, Skolithos, Teichichnus, and Undichna fits to the following criteria for brackish settings: absence of "marine" trace fossils and presumed generalist behaviour of tracemakers. Most of other criteria cannot be applied, as there is no assemblage of evidently normal salinity in the neighbourhood of the locality, which would serve as a source of comparative data. To conclude, there is only a weak evidence for a lowered salinity in the ichnologic record but no evidence excludes this possibility.

\section{Conclusions}

The easternmost part of the Laurussia ("Old Red") supercontinent provided data on trace fossil density and diversity from the localities at the Andoma Hill. Lower part of the studied sequence (upper Givetian) is not bioturbated and bears sedimentological features of fluvial settings. In the earliest Frasnian (lower to middle part of the Andoma Formation), a relatively diverse ichnoassemblage was found, comprising the following ichnogenera: ?Arenituba, Cochlichnus, Cruziana, Diplocraterion, Lockeia, Palaeophycus, Planolites, Rusophycus, Skolithos, Teichichnus, and Undichna. It can be characterized as mixed Skolithos-Cruziana ichnofacies.

Ichnofossils and accompanying sedimentological data show that sediments of the Andoma Formation formed probably in the wave and tide influenced shallow water environment, above the wave base. The existing evidence allows us to present a hypothesis that the lower to middle part of the Andoma Formation originated in brackish-water estuarine settings. Absence of typical "marine" ichnogenera in the otherwise diverse ichnoassemblage is the most important evidence among the obligatory criteria for recognition of brackish water ichnoassemblages.

Further progress in interpretation of the Old Red Sandstone facies at the Onega Lake would be possible in the case of obtaining new data that would allow evaluating longitudinal trends of possible landwards freshening of depositional waters.

\section{Acknowledgments}

All members of the field teams of the 2002-2007 field seasons are acknowledged for field assistance. The study belongs to the Research Program of the Institute of Geology, ASCR, Prague, No. AV0Z 301305516. The authors thank Alfred Uchman (Cracow) and an anonymous reviewer for their helpful comments. This paper is a contribution to the IGCP 596 project.

\section{References}

AlPert, S.P. 1974. Systematic review of the genus Skolithos. Journal of Paleontology 48, 661-669.

AlPERT, S.P. 1975. Planolites and Skolithos from the upper Precambrian-Lower Cambrian White-Inyo Mountains, California. Journal of Paleontology 49, 508-521.

BALDwIN, C.T. 1977. Rusophycus morgati: an asaphid produces trace fossil from the Cambro-Ordovician of Brittany and northwest Spain. Journal of Paleontology 51, 411-413.

BARKhatova, V.P. 1941. On the geology of basins at the southeastern bank of the Onega Lake and the upper stream of the Onega River. Trudy Severnogo Geologicheskogo Upravleniya 9, 1-116. [in Russian]

BJERSTEDT, T.W. 1988. Multivariate analyses of trace fossil distribution from an Early Mississippian oxygen-deficient basin, Central Appalachians. Palaios 3, 53-68. DOI 10.2307/3514544 
Bjerstedt, T.W. \& Erickson, J.M. 1989. Trace fossils and bioturbation in peritidal facies of the Potsdam-Theresa Formations (Cambrian-Ordovician), northwest Adirondacks. Palaios 4, 203-224. DOI 10.2307/3514770

Blomeier, D., WisshaK, M., Dallmann, W., Volohonsky, E. \& Freiwald, A. 2003. Facies analysis of the Old Red Sandstone of Spitsbergen (Wood Bay Formation): Reconstruction of the depositional environments and implications of basin development. Facies 49, 151-174.

Bromley, R.G. 1996. Trace Fossils: Biology, Taphonomy and Applications. 361 pp. Chapman \& Hall, London.

Buatois, L.A., Mángano, M.G., Genise, J.F. \& Taylor, T.N. 1998. The ichnologic record of the continental invertebrate invasion: evolutionary trends in environmental expansion, ecospace, utilization, and behavioral complexity. Palaios 13, 217-240. DOI 10.2307/3515447

Carroll, S. \& Trewin, N.H. 1995. Cornulatichnus: a new trace fossil from the Old Red Sandstone of Orkney. Scottish Journal of Geology 37, 37-41. DOI 10.1144/sjg31010037

CRimes, T.P. 1975. The stratigraphical significance of trace fossils, 109-130. In FREY, R.W. (ed.) The Study of Trace Fossils. Springer-Verlag, New York.

CRimes, T.P. 1987. Trace fossils and correlation of late Precambrian and early Cambrian strata. Geological Magazine 124(2), 97-119. DOI 10.1017/S0016756800015922

Crimes, T.P. \& Harper, J.C. (eds) 1977. Trace fossils 2. Geological Journal, Special Issue 9, 1-364.

Crimes, T.P. \& MArcos, A. 1976. Trilobite traces and the age of the lowest part of the Ordovician reference section for NW Spain. Geological Magazine 113, 349-356. DOI 10.1017/S0016756800047622

Droser, M.L. \& BotTJER, D.J. 1986. A semiquantitative field classification of ichnofabric. Sedimentary Petrology 56(4), 558-559.

ENGALYCHEV, S.Y. 2003. A new data on inchnotextures from the sandy deposits of the Main Devonian Field. Vestnik $S P b G U$, Series 7, Geology and Geography 3(23), 97-102. [in Russian]

Engalychev, S.Y. \& Nikitin, M.Y. 2001. Nekotorye litologicheskie osobennosti i vozmozhnyi genesis "rybnyh brekchij" iz verhnedevonskikh otlozhenij Andomy-gory (Some lithological aspects and possible origin of the "fish-breccias" in the Upper Devonian deposits of Andoma Hill), 74-81. In NESTEROv, E.M. (ed.) Istoricheskaya geologiya i evolyutsionnaya geografiya. NOU Amadeus, Saint Petersburg.

ERofeEv, V. 1846. On outcrops of Old Red Sandstones at the Andoma Hill. Mining Journal 1(1), 1-13. [in Russian]

Esin, D., Ginter, M., Ivanov, A., Lebedev, O., Luksevics, E., Avkhimovich, V., Golubtsov, V. \& Petukhova, L. 2000. Vertebrate correlation of the Upper Devonian and Lower Carboniferous on the East European Platform. Courier Forschungsinstitut Senckenberg 223, 341-359.

Fillion, D. \& Pickerill, R.K. 1990. Ichnology of the Lower Ordovician Bell Island and Wabana Groups of eastern Newfoundland. Palaeontographica Canadiana 7, 1-119.

Fillmore, D.L., Lucas, S.G. \& Simpson, E.L. 2011. The fish swimming trace Undichna from the Mississippian Mauch Chunk Formation, Eastern Pennsylvania. Ichnos 18(1), 27-34. DOI 10.1080/10420940.2011.552579

Frey, R.W. \& Bromley, R.G. 1985. Ichnology of American chalks: the Selma Group (Upper Cretaceous), western Alabama. Canadian Journal of Earth Science 22, 801-828. DOI 10.1139/e85-087

FreY, R.W. \& Howard, J.D. 1982. Trace fossils from the Upper
Cretaceous of the Western Interior: potential criteria for facies models. The Mountain Geologist 19, 1-10.

Frey, R.W. \& Pemberton, S.G. 1984. Trace fossil facies models. Geoscience Canada Reprint Series 1, 189-207.

Friend, P.F., Williams, B.P.J., Ford, M. \& Williams, E.A. 2000. Kinematics and dynamics of Old Red Sandstone basins, 29-60. In Friend, P.F. \& Williams, B.P.J. (eds) New perspectives on the Old Red Sandstone. Geological Society of London, Special Publication 180.

FÜRSICH, F.T. 1974. On Diplocraterion Torell 1870 and the significance of morphological features in vertical, spreiten-bearing, U-shaped trace fossils. Journal of Paleontology 48(5), 952-962.

Gingras, M.K., MacEachern, J.A., Dashtgard, S.E., Zonneveld, J.-P., Schoengut, J., Ranger, M. \& Pemberton, S.G. 2012. Estuaries, 463-497. In Knaust, D. \& BRomLey, R.G. (eds) Trace Fossils as Indicators of Sedimentary Environments. Developments in Sedimentology 64. Elsevier, Amsterdam.

Gregory, M.R., Campbell, K.A., Zuraida, R. \& Martin, A.J. 2006. Plant traces resembling Skolithos. Ichnos 13(4), 205-216. DOI 10.1080/10420940600843617

HAN, Y. \& Pickerill, R.K. 1994. Phycodes templus isp. nov. from the Lower Devonian of northwestern New Brunswick, eastern Canada. Atlantic Geology 30(1), 37-46.

Häntzschel, W. 1975. Trace fossils and problematica, 1-269. In Teichert, C. (ed.) Treatise on Invertebrate Paleontology, Part $W$, Supplement 1. Geological Society of America and University of Kansas, Boulder \& Lawrence.

HeCKER, R.F. 1930. On finding of Rhizocorallium in the Volkhov Devonian. Ezhegodnik Russkogo Paleontologicheskogo Obschestva 8, 150-156. [in Russian]

Ivanov, A.O. 1990. Snetnaya Gora vertebrate assemblage from the Main Devonian Field and its biostratigraphical significance. Vestnik Leningradskogo Universiteta, Series 7, Geology and Stratigraphy 1, 94-98. [in Russian]

Ivanov, A., LuKšEvičs, E., Stinkulis, Ģ., Tovmasyan, K., Zupinšs, I. \& Beznosov, P. 2006. Stratigraphy of the Devonian deposits at Andoma Hill, 385-396. In Pystin, A.M. (ed.) Problemy Geologii i Mineralogii. Geoprint, Syktyvkar. [in Russian]

Ivanov, A., Zhuravlev, A., Stinkulis, Ģ., Evdokimova, I., Dronov, A., Sokiran, E., Shishlov, S., Broushrin, A. \& MYshKINA, N. 2005. Devonian Sections of North-West of the East European Platform. 74 pp. St. Petersburg University Publishing House, Saint Petersburg.

Knaust, D. \& Bromley, R.G. (eds) 2012. Trace Fossils as Indicators of Sedimentary Environments. Developments in Sedimentology 64. 924 pp. Elsevier, Amsterdam.

KsiAż̇iewicz, M. 1977. Trace fossils in the flysch of the Polish Carpathians. Paleontologia Polonica 36, 1-208.

MacEachern, J.A. \& Pemberton, S.G. 1994. Ichnological aspects of incised valley fill systems from the Viking Formation of the Western Canada Sedimentary Basin, Alberta, Canada, 129-157. In Boyd, R., Zaitlin, B.A. \& Dalrymple, R. (eds) Incised valley systems - origin and sedimentary sequences. Society of Economic Paleontologists and Mineralogists, Special Publication 51.

Maples, C.G. \& SutTner, L.J. 1990. Trace fossils and marinenonmarine cyclicity in the Fontain Formation (Pennsylvanian: Morrowan/Atokan) near Manitou Springs, Colorado. Journal of Paleontology 64(6), 859-880.

Mikuláš, R. \& Dronov, A. 2006. Palaeoichnology - Introduction to the Study of Trace Fossils. 122 pp. Institute of Geology, 
Academy of Sciences of Czech Republic, Prague. [in Russian with English summary]

MinTER, N.J. \& BRADDY, S.J. 2006. The fish and amphibian swimming traces Undichna and Lunichnium, with examples from the Lower Permian of New Mexico, USA. Palaeontology 49, 1123-1142. DOI 10.1111/j.1475-4983.2006.00588.x

Morrissey, L.B. \& BRADDY, S.J. 2004. Terrestrial trace fossils from the Lower Old Red Sandstone, southwest Wales. Geological Journal 39, 315-336. DOI 10.1002/gj.991

NATHORst, A.G. 1881. Om spâr af evertebrerade djur m. m. oc deras paleotologiska betydelse (with abridged French translation: Mémoire sur quelques traces d'animaux sans vertèbres etc. et de leur portée paléontologique, pp. 61-104). Kongliga Svenska Vetenskaps-Akademiens Handlingar 18, 1-104.

Obruchev, D. \& Mark-KuriK, E. 1965. Devonian Psammosteids (Agnatha, Psammosteidae) of the USSR. 256 pp. Tallin. [in Russian with English summary]

Osgood, R.G. 1970. Trace fossils of the Cincinnati area. Paleontographica Americana 6, 281-444.

PAnder, C. 1857. Über die Placodermen des devonischen Systems. 106 pp. Buchdruckerei der Kaiserlichen Akademie der Wissenschaften, Saint Petersburg.

Pemberton, S.G. 1992. Applications of ichnology to petroleum exploration - A core workshop. Society of Economic Paleontologists and Mineralogists Core Workshop 17. 429 pp. SEPM, Tulsa.

Pemberton, S.G. \& Frey, R.W. 1982. Trace fossil nomenclature and the Planolites-Palaeophycus dilemma. Journal of Paleontology 56, 846-881.

Pemberton, S.G., MacEachern, J.A. \& Ranger, M.J. 1992. Ichnology and event stratigraphy - the use of trace fossils in recognizing tempestites, 85-117. In Pemberton, S.G. (ed.) Applications of ichnology to petroleum exploration. Society of Economic Paleontologists and Mineralogists Core Workshop 17. SEPM, Tulsa.

Pemberton, S.G., Reinson, G.E. \& MacEachern, J.A. 1992. Comparative ichnological analysis of Late Albian estuarine valley-fill and shelf-shoreface deposits, Crystal Viking Field, Alberta, 291-317. In Pemberton, S.G. (ed.) Applications of ichnology to petroleum exploration. Society of Economic Paleontologists and Mineralogists Core Workshop 17. SEPM, Tulsa.

Pemberton, S.G. \& Wightman, D.M. 1992. Ichnological characteristics of brackish water deposits, 141-167. In PEMBERTON, S.G. (ed.) Applications of ichnology to petroleum exploration. Society of Economic Paleontologists and Mineralogists Core Workshop 17. SEPM, Tulsa.

Petrov, L.S. 1956. Devonian deposits of the north-western part of Russian platform. Trudy VNIGRI, New Series 97, 1-174. [in Russian]

PICKERILL, R.K. 1982. Glockerichnus, a new name for the trace fossil ichnogenus Glockeria Książkiewicz 1968. Journal of Paleontology 56, 816.

Ranger, M.J. \& Pemberton, S.G. 1992. The sedimentology and ichnology of estuarine point bars in the McMurray Formation of the Athabasca Oil Sands Deposit, northeastern Alberta, Canada, 401-421. In Pemberton, S.G. (ed.) Applications of Ichnology to Petroleum Exploration. Society of Economic Paleontologists and Mineralogists Core Workshop 17. SEPM, Tulsa.

REINECK, H.A. 1963. Sedimentgefüge im Bereich der südlichen Nordsee. Abhandlungen Senckenbergische Naturforschenden Gesellschaft 505, 1-138.
SAVRdA, C.E. \& BotTJer, D.J. 1986. Trace fossil model for reconstruction of paleo-oxygenation in bottom water. Geology 14, 3-6. DOI 10.1130/0091-7613(1986)14<3:TMFROP >2.0.CO;2

SAVRDA, C.E. \& BotTJER, D.J. 1987. Trace fossils as indicators of bottom-water redox conditions in ancient marine environments. In BotTJER, D.J. (ed.) New concepts in the use of biogenic sedimentary structures for paleoenvironmental interpretation. Volume and Guidebook 52.

SChliRf, M. \& UChman, A. 2005. Revision of the ichnogenus Sabellarifex Richter, 1921 and its relationship to Skolithos Haldeman, 1840 and Polykladichnus Fürsich, 1981. Journal of Systematic Palaeontology 3(2), 115-131. DOI 10.1017/S1477201905001550

Schlirf, M., Uchman, A. \& KüMmel, M. 2011. Upper Triassic (Keuper) non-marine trace fossils from the Haßberge area (Franconia, south-eastern Germany). Paläontologische Zeitschrift 75(1), 71-96.

SeIlacher, A. 1953. Studien zur Palichnologie. I. Über die Methoden der Palichnologie. Neues Jahrbuch für Geologie und Paläontologie, Abhandlungen 96, 421-452.

SeILACher, A. 1955. Spuren und Fazies im Unterkambrium. Akademie der Wissenschaften und Literatur Mainz, Abhandlungen, mathematisch-naturwissenschaftichen Klasse 10, 373-399.

SeILACHER, A. 1967a. Bathymetry of trace fossils. Marine Geology 5, 413-428. DOI 10.1016/0025-3227(67)90051-5

SeILACHER, A. 1967b. Fossil behaviour. Scientific American 217, 72-80. DOI 10.1038/scientificamerican0867-72

SeILACHER, A. 1970. Cruziana stratigraphy of 'non-fossiliferous' Paleozoic sandstones, 447-476. In CRIMES, T.P. \& HARPER, J.C. (eds) Trace fossils. Geological Journal Special Issue 3.

SeILACHER, A. 1994. How valid is Cruziana stratigraphy? Geologische Rundschau 83, 752-758. DOI 10.1007/BF00251073

Sмiтh, J. 1909. Upland fauna of the Old Red Sandstone Formation of Carrick, Ayrshire. 60 pp. Kilwinning, Cross.

Snigirevskaya, N.S. \& SNigiRevsky, S.M. 2001. New locality of Callixylon (Archaeopteridaceae) in the Late Devonian of Andoma Mountain (Vologda Region, north-west Russia) and its importance for the reconstruction of archaeopterids distribution. Acta Palaeobotanica 41(2), 97-105.

StAnley, D.C.A. \& Pickerill, R.K. 1995. Arenituba, a new name for the trace fossil ichnogenus Micatuba Chamberlain, 1971. Journal of Paleontology 69, 612-614.

Tovmasyan, K. \& Stinkulis, Ģ. 2008. Implications of fluvial, tidal and wave processes to the deposition of siliciclastic sequence of Devonian, Andoma Hill, 71. In HinTs, O., AinsAAR, L., MänniK, P. \& Meidla, T. (eds) The Seventh Baltic Stratigraphical Conference. Abstracts and Field Guide. Geological Society of Estonia, Tallinn.

Trewin, N.H. 2000. The ichnogenus Undichna, with examples from the Permian of the Falkland Islands. Palaeontology 6(6), 979-997. DOI 10.1111/1475-4983.00158

Uchman, A. 2010. A new ichnogenus Skolichnus for Chondrites hoernesii Ettingshausen, 1863, a deep-sea radial trace fossil from the Upper Cretaceous of the Polish Flysch Carpathians: Its taxonomy and palaeoecological interpretation as a deeptier chemichnion. Cretaceous Research 31(5), 515-523. DOI 10.1016/j.cretres.2010.07.002

Zaituin, B.A., Dalrymple, R.W. \& Boyd, R. 1994. The stratigraphic organization of incised valley systems associated with relative sea-level change, 45-60. In DALRYMPLE, R.W., BOYD, R. \& ZAitLin, B.A. (eds) Incised valley systems: origin and sedimentary sequences. SEPM Special Publication 51. 